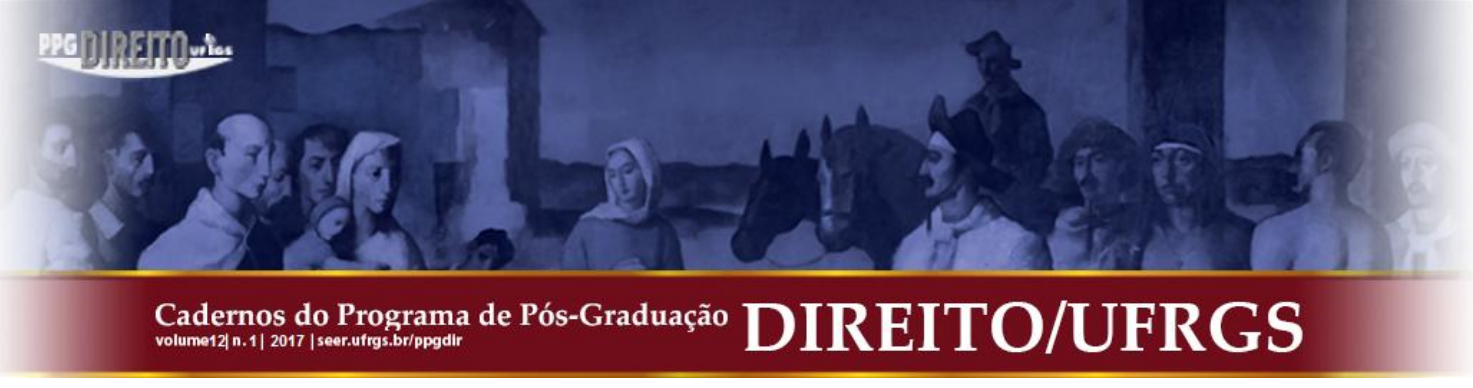

\title{
AS INDICAÇÕES GEOGRÁFICAS E O DIREITO DE PROPRIEDADE
}

\author{
GEOGRAPHICAL INDICATIONS AND PROPERTY RIGHTS
}

Junior Cesar Bueno e Freitas*

\begin{abstract}
RESUMO: Este artigo debate a natureza jurídica das indicações geográficas no contexto do direito de propriedade. Discutem-se as teorias de Demolombe, Kant, Proudhon, Pufendorff, dentre outros, que levaram a incluir o direito de propriedade no rol dos direitos reais, sem desconsiderar a dicotomia entre domínio e propriedade. Com base nesta dialética, debate-se a natureza jurídica da propriedade imaterial, em suas diversas classificações, que possibilitariam inserir o instituto das indicações geográficas, considerando-se neste trabalho as indicações de procedência e as denominações de origem, dentro de um sistema amparado pelo domínio universal e pelos direitos do conhecimento. Este trabalho é o resultado de uma pesquisa doutrinária embasada no método crítico dialético.
\end{abstract}

PALAVRAS-CHAVE: Direito Agrário. Propriedade Intelectual. Indicações Geográficas.

\begin{abstract}
This paper debates geographical indications regarding to its legal concept and property rights. It discusses theories developed by Demolombe, Kant, Proudhon, Pufendorff, among others, that led to include property rights in the bundle of rights list, without ignoring the dichotomy between domain and property. Based on dialectic, it talks about legal concept of intangible property in its different sorts, which would make possible to understand the Institute of geographical indications, such as protected designation of origin and protected geographical indication, within a supported system by universal dominion and knowledge of rights. This work results from doctrinal research made on dialectical critical method.
\end{abstract}

KEYWORDS: Agrarian Law. Intellectual Property. Geographical Indications.

SUMÁRIO: Introdução. 1 Teorias Sobre a Natureza Jurídica da Propriedade. 2 As Indicações Geográficas e o Direito de Propriedade. 3 Natureza Jurídica das Indicações Geográficas. Conclusão. Referências.

\section{INTRODUÇÃO}

Com base em pesquisa doutrinária, subsidiada pelo método crítico dialético, foi concebido este artigo, que busca discutir a natureza jurídica das indicações geográficas.

O tema deste trabalho está associado aos fundamentos teóricos-filosóficos da experiência jurídica. Discute-se as teorias mais importantes que amparam a natureza da propriedade. Em um discurso cronológico se estabelece um confronto crítico sobre a natureza jurídica das indicações geográficas que é dialeticamente confrontada ao direito de propriedade.

A regulação das indicações geográficas é estabelecida na Lei de Propriedade Industrial e tem sido objeto de relevantes discussões na doutrina estrangeira e no Brasil, desde Pontes de Miranda, que comentava este instituto do antigo Código de Propriedade Industrial.

\footnotetext{
* Mestre em Direito Agrário pela Universidade Federal de Goiás (UFG). Especialista em Direito Processual Civil pela Universidade Federal de Goiás (UFG). Consultor da Organização das Nações Unidas para a Educação, Ciência e Cultura (UNESCO) junto ao Ministério da Justiça, no período de 2014. Advogado e professor de Direito Administrativo na Faculdade de Direito da Escola Superior Associada de Goiânia (ESUP/FGV), Goiás.
} 


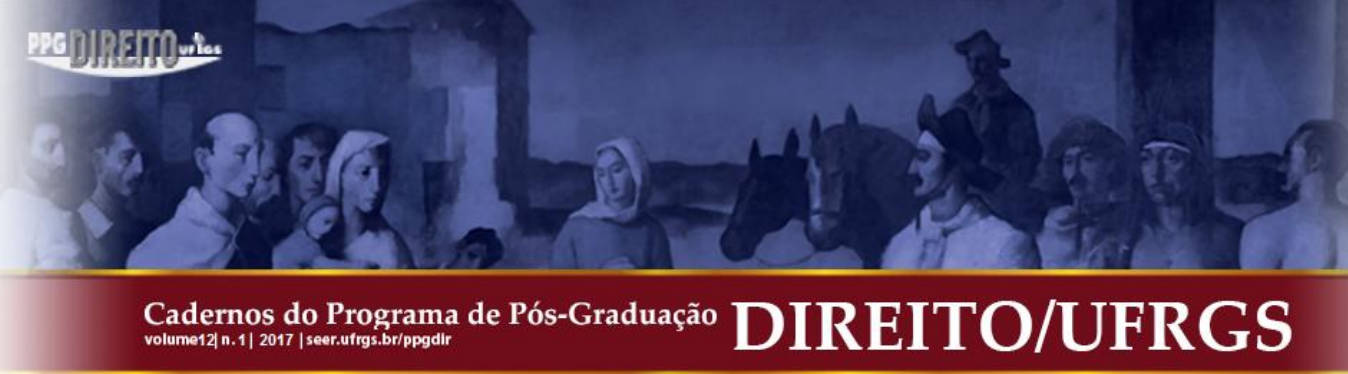

As indicações geográficas é uma figura impar no rol da propriedade intelectual, dos direitos do conhecimento ou mesmo, sob a vertente da classificação brasileira da denominada propriedade industrial, em que é regulamentada na Lei nº 9.279/1996.

A lei brasileira define o instituto das indicações geográficas (IG) sob a forma de indicação de procedência (IP) e denominação de origem (DO). Sob o aspecto legal, o art. 177 da Lei de Propriedade Industrial define a indicação de procedência como: "o nome geográfíco de país, cidade, região ou localidade de seu território, que se tenha tornado conhecido como centro de extração, produção ou fabricação de determinado produto ou de prestação de determinado serviço" $"$.

Já o art. 178 concebe a denominação de origem como: “o nome geográfico de país, cidade, região ou localidade de seu território, que designe produto ou serviço cujas qualidades ou características se devam exclusiva ou essencialmente ao meio geográfico, incluídos fatores naturais e humanos",2.

As indicações geográficas, protegidas no âmbito da Organização Mundial do 301 Comércio, têm se destacado como um fator de essencial importância para as matrizes estratégicas do comércio internacional, principalmente de produtos ligados à agricultura, à pecuária e ao extrativismo. São conhecidas em todo o mundo como ferramentas utilizadas pelos países europeus, principalmente, França, Portugal, Itália, Grécia e Espanha, para a valorização de seus produtos no mercado internacional.

São exemplos do rol concebido sob a forma de indicações geográficas as denominações de vinhos como Champagne, Porto e Chianti; de queijos como o Roquefort, Vacherin-mont- d'or, Camembert de Normandie, além de outras frutas, legumes e produtos transformados reconhecidos internacionalmente. A título de exemplo, podem ser citadas no Brasil as indicações de procedência (IP): Vale dos Vinhedos (vinhos), Região da Serra da Mantiqueira de Minas Gerais (café). Também as denominações de origem (DO): Litoral Norte Gaúcho (arroz) e Ortigueira (mel).

Embora seja um instituto jurídico bastante antigo, pois em 1716 o Grão-Duque da Toscana tenha determinado a demarcação da região produtora do vinho Chianti e em 1756 a Companhia da Agricultura das Vinhas do Alto Douro, com a finalidade de assegurar a

\footnotetext{
${ }^{1}$ BRASIL. Lei 9.279, de 14 de maio de 1996. Regula direitos e obrigações relativos à propriedade industrial. Diário Oficial da União, de 15 de maio $1996 . \quad$ Disponivel em: <http://www.planalto.gov.br/ccivil/leis/L9279.htm>. Acesso em: 20 jul. 2016.

${ }^{2}$ Idem. 


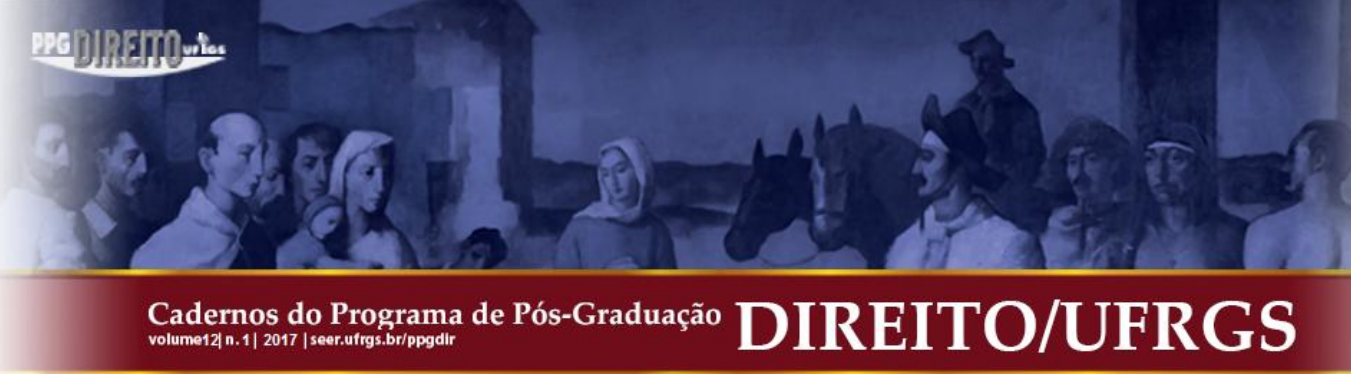

qualidade de seus vinhos e coibir adulterações, efetuou a primeira demarcação das feitorias da Região do Douro (Portugal), o instituto das indicações geográficas, efetivamente, inicia-se no Brasil a partir do ano 2000 com o pedido de reconhecimento do Vale dos Vinhedos (Serra Gaúcha) como indicação de procedência. Desde então as indicações geográficas têm despertado interesse no Brasil.

Dados coletados junto ao Instituto Nacional da Propriedade Industrial - INPI, em 2012 apresentavam o registro efetivo de 3 denominações de origem nacionais e o registro de reconhecimento de 3 denominações de origem internacionais (já reconhecidas nos países de origem más que buscam a proteção contra os similares nacionais), e de outras 15 indicações de procedência.

Em 2016, o INPI apresentou o registro de 9 denominações de origem nacionais e 8 estrangeiras. Com relação à indicação de procedência, o resultado foi de 39 registros concedidos. Em termos percentuais, os dados comparativos colhidos em 2012 com as informações atuais, apresentaram um crescimento real de $183 \%$ em relação às denominações de origem e de $160 \%$, em relação à Indicação de procedência.

A discussão suscitada neste artigo busca compreender a natureza jurídica das indicações geográficas, inseridas no âmbito dos direitos sobre a propriedade industrial, mas que tem imensa aplicação na indústria de transformação primária e que tem despertado atenção e se tornado objeto de estudo do Direito Agrário.

\section{TEORIAS SOBRE A NATUREZA JURÍDICA DA PROPRIEDADE}

A gênese da propriedade se desenvolve a partir do direito privado romano, no direito canônico e finalmente no direito civil, mas sempre conservando as suas bases jus filosóficas.

Indaga-se primeiramente, se seria a propriedade um direito real em sua essência?

Em princípio seria uma pergunta impertinente, pois a codificação civil brasileira herdeira da tradição civilista francesa, como direito real a define. Desde o Código Bevilaqua até o Código Civil de 2002, conforme está alicerçado no artigo 1.225. Entretanto uma análise sobre o domínio e o direito de propriedade se faz necessária, mesmo que em rápidas linhas, para se entender a relação intrínseca entre ambos em um contexto ontológico. 
A concepção sobre direitos reais do séc. XIX, que deu origem ao conceito que conhecemos nos dias atuais, formou-se a partir da evolução histórico-jurídica, oriunda da "escola de bolonha", iniciada no séc. XI, e de seus glosadores, a partir do séc. XII.

Segundo Moreira Alves, os jurisconsultos romanos não faziam a distinção entre direitos reais e pessoais no plano material, mas apenas no plano processual por meio da actio in rem (ação real) e da actio in personam (ação pessoal). Na ação real o autor afirmava o seu direito sobre a coisa, sendo oponível erga omnes, entretanto o réu somente era conhecido no momento da violação do direito subjetivo, pois havia um dever geral de abstenção. Na ação pessoal, o autor reclamava contra obrigação em que o réu deixara de cumprir, pois sendo devedor, era o único que se obrigava a satisfazer o direito subjetivo. Direitos reais para os romanos seriam, portanto, os direitos que se violados ensejariam a utilização da actio in rem. ${ }^{4}$

No direito privado romano os direitos reais agrupavam-se em duas categorias. De um lado o direito de propriedade e de outro, os direitos sobre coisa alheia (iura in re aliena), ou direitos reais limitados ${ }^{5}$. Esses direitos tiveram conotações distintas no direito clássico e no direito justinianeu ${ }^{6}$.

O direito clássico considerava iura in re aliena: as seruites (mais tarde denominadas de servidões prediais), o ususfructus (usufruto), o usus (uso), o pignus datum (penhor), e o pignus conuentum ou hypotheca (hipoteca). ${ }^{7}$

No direito justinianeu foram incorporadas à iura in re aliena: a emphiteusis (enfiteuse) e as superficies (superfícies). As seruites passaram a abranger as servidões, que vinham do direito clássico e que mais tarde foram denominadas "servidões prediais". Neste período, na categoria de "servidões pessoais", agruparam-se: usufructus e usus, habitatio; operae seruorum (serviço de escravos), e as operae alterius animalium (serviços de animais e outrem), que surgiram como direitos reais autônomos. ${ }^{8}$

\footnotetext{
${ }^{3}$ Para maiores aprofundamentos sobre a escola de bolonha e as Glosas Ordinárias, recomenda-se a leitura de: WIEACKER, Franz. História do direito privado moderno. Tradução de A.M. Botelho Hespanha. 3. ed. Lisboa: Fundação Calouste Gulbenkian, 2004, p. 38-59.

${ }^{4}$ Vide ALVES, José Carlos Moreira. Direito romano. 11. ed. v. 1. Rio de Janeiro: Forense, 1998, p. 258.

${ }^{5}$ ALVES, José Carlos Moreira. op. cit., p. 258-259.

${ }^{6}$ Na história do Direito Romano, designa-se como direito clássico o período compreendido entre 126 a.C., até o término do reinado de Diocleciano, em 305 d.C. Direito Justinianeu é a designação dada ao direito vigente no reinado de Justiniano, de 527 a 565 d.C., compreendido historicamente dentro do período denominado direito pós-classico ou romano-helênico, de 305 d.C a 565 d.C. (vide ALVES, José Carlos Moreira. op. cit., p. 2).

${ }^{7}$ Vide ALVES, José Carlos Moreira. op. cit., p. 259.

${ }^{8}$ ALVES, José Carlos Moreira. op. cit., p. 259.
} 
Max Kaser fala que a antiga propriedade romana incluiu antecedentes dos direitos reais limitados e que:

\begin{abstract}
A propriedade romana primitiva da época rural é uma manifestação do amplo poder doméstico que o paterfamilia tem que ter sobre determinadas pessoas (a pátria potestas sobre os filhos de família, a manus sobre a mulher), quer sobre os bens materiais. Apesar de, neste período, não haver ainda um nome que designe o poder sobre as COISAS, é entendido como distinto do poder sobre as pessoas. ${ }^{9}$
\end{abstract}

Antes do séc. XII, a concepção sobre direitos reais e pessoais não existia sob a forma de direitos materiais, mas apenas sob uma classificação subjetiva, mais condizente com as necessidades da época para a satisfação dos direitos porventura ofendidos.

A construção histórico-jurídica que se busca demonstrar, evidencia, que tanto a categoria de direitos reais ou pessoais, quanto o direito de propriedade (originalmente concebido sob a forma de bens corpóreos) foi uma construção sobre a qual se chegou a um consenso, diga-se limitado, e que não é tido por absoluto, mesmo nos dias atuais.

Para Washington de Barros, os romanos jamais chegaram a arquitetar uma teoria sobre os direitos reais, tanto que as expressões jus in re e jus ad rem, empregadas para distinguir os direitos reais dos pessoais, surgiu primeiramente no direito canônico do séc. XII, com o intuito de designar direitos patrimoniais de natureza diversa, vindo a se incorporar, posteriormente, nas legislações modernas. ${ }^{10}$

O direito civil da primeira metade do séc. XIX compreendia a propriedade como direito exclusivo e absoluto de uma pessoa sobre as coisas materiais. Essa compreensão se incorporou ao Código Civil dos Franceses $^{11}$, que serviu de modelo para as modernas codificações de tradição latina. A ideia jurídica de direito de propriedade passou a se concentrar em uma classificação que lhe desse primazia em relação aos demais direitos ${ }^{12}$.

\footnotetext{
9 KASER, Max. Direito privado romano. Tradução de Samuel Rodrigues e Ferdinand Hämmerle. Lisboa: Fundação Calouste Gulbenkian, 1999, p. 137.

${ }^{10}$ Vide MONTEIRO, Washington de Barros. Curso de direito civil. 36. ed. v. 3. São Paulo: Saraiva, 2000, p. 8 9.

${ }^{11}$ Article 544. La propriété est le droit de jouir et disposer des choses de la manière la plus absolue, pourvu qu'on n'en fasse pas um usage prohibé par les lois ou par les reglemens. (FRANCE. Code civil des français: édition originale et seule officielle. A Paris, de l'Imprimerie de la République An XII 1804, p. 134. Disponível em: <http://www.assemblee-nationale.fr/evenements/code-civil-1804-1.asp>. Acesso em: 20 jul. 2016).

12 A primazia que erigiu o direito de propriedade como o mais característico dos direitos reais, a ponto de integrar as codificações nacionais modernas, ao final do séc. XVIII, como direito absoluto, parte de uma concepção filosófica complexa, que deve ser analisada a partir da leitura das obras de Santo Tomas de Aquino, São Basílio, Bartolomé de Las Casas, Lock e Voltaire, principalmente. Essa análise é bem fundamentada pelo prof. Carlos Frederico Marés (MARÉS, Carlos Frederico. Função social da terra. Porto Alegre: Sérgio Antônio Fabris Editor, 2003). Obra que se recomenda para maiores aprofundamentos.
} 


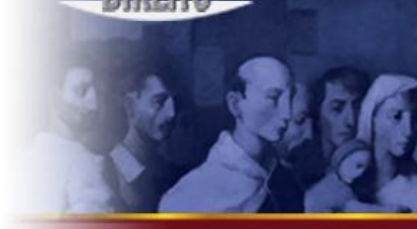

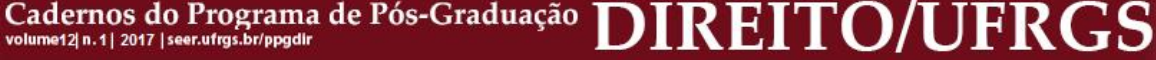

Segundo Demolombe, a propriedade era arquétipo dos direitos reais: "a propriedade é evidentemente o primeiro e o mais completo dos direitos reais; é direito real por excelência"13.

Para Christophe Grzegorczyk é o proprietário quem caracteriza o sujeito de direito e não a subjetividade jurídica que caracteriza o proprietário. Grzegorczyk Reafirma as clássicas lições de Demolombe que atribuía ao sujeito de direito uma característica essencialmente ativa enquanto o objeto de direito seria necessariamente passivo, o que definiu uma análise do dualismo antológico que Demolombe atribuiu ao sujeito de direito e ao objeto jurídico:

O direito real é aquele que cria entre a pessoa e a coisa uma relação direta e imediata; de modo que pode ser encontrado dois elementos, a saber: a pessoa, que é o sujeito ativo de direito, e a coisa, que é o objeto.

Ao contrário, chamamos de direito pessoal, aquele que cria somente uma relação entre a pessoa, a qual detém o direito, e outra pessoa que se obriga perante aquela, por causa de uma coisa ou de um fato qualquer; de modo que encontramos três elementos, a saber: a pessoa que é o objeto ativo de direito (o credor); a pessoa que é o sujeito passivo (o devedor): e a coisa (ou o fato) que é o objeto. (Tradução nossa) ${ }^{14}$

Em essência, Mikhaïl Xifaras, ao discorrer sobre a natureza dos direitos reais e pessoais, nos mostra que em relação à sua natureza jurídica, nada de novo foi implementado desde o séc. XIX. Para Xifaras o direito real é um direito imediato e direto de uma pessoa sobre uma coisa, enquanto o direito pessoal é essencialmente ternário, pois ocorre entre duas pessoas consideradas, uma ativa e outra passiva, em relação ao objeto de direito. ${ }^{15}$ Essa dualidade entre a pessoa e a coisa, na qual se desejava estabelecer a relação jurídica de direito real, era objeto de análise desde o séc. XVIII. Immanuel Kant dentre outros, entedia ser contraditória estabelecer tal afinidade no direito de propriedade. Kant Indagava: "como uma

\footnotetext{
${ }^{13}$ DEMOLOMBE, Charles. Traité de la distinction des personnes et des biens. Cours de Code Napoléon. Tomo IX. Paris: Durand, 1870, n. 471, p. 352, apud XIFARAS, Mikhaïl. La propriété: étude de philosophie de droit. Collection Fondements de la Politique. Paris: Press Universitaires de France, 2004, p. 28 .

14 "Le droit réel est celui qui crée entre la personne et la chose une relation directe et immédiate; de telle sorte qu'on ne trouve que deux éléments, savoir: la personne, qui est le sujet actif du droit, et la chose, qui en est l'objet. On appelle au contraire droit personnel, celui qui crée seulement une relation entre la personne, à laquelle le droit appartient,et une autre personne qui est obligée envers elle, à raison d'une chose ou d'un fait quelconque; de telle sorte que l'on trouve trois éléments, savoir: la personne qui est le sujet actif du droit (le créancier); la personne qui en est le sujet passif (le débiteur): et la chose (ou le fait) qui en est l'objet." (Charles DEMOLOMBE, Charles. op. cit.,( n. 464, p. 336) apud XIFARAS, Mikhaïl. op. cit., 2004, p. 29).

${ }^{15}$ Vide XIFARAS, Mikhaïl. La propriété: étude de philosophie de droit. Collection Fondements de la Politique. Paris: Press Universitaires de France, 2004, p. 30.
} 


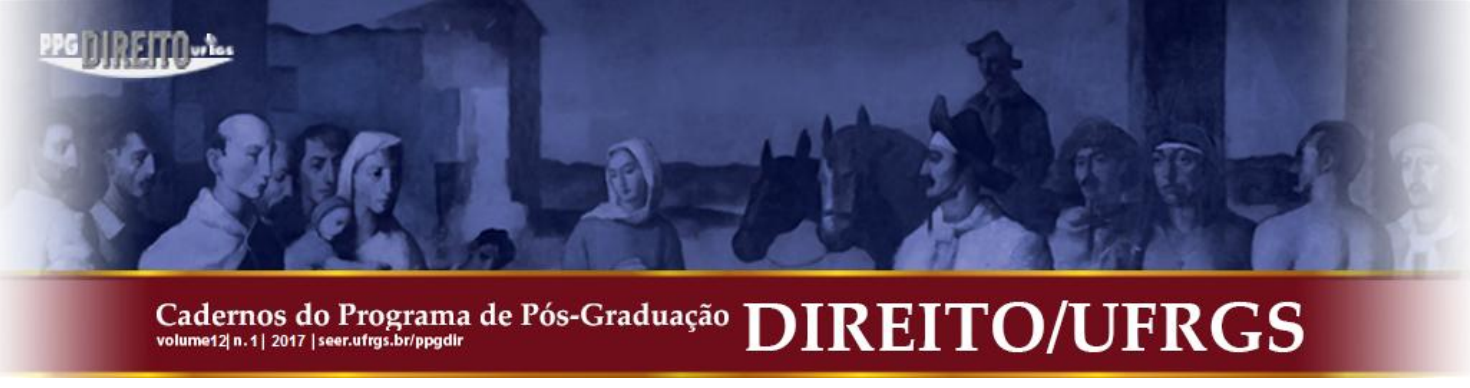

relação jurídica pode unir uma pessoa com uma coisa, incapaz por definição de qualquer relação jurídica que fosse?"

À par das ideias de Kant e Planiou sobre a natureza jurídica da propriedade, Demolombe estruturara a sua teoria com base no modo de aquisição da propriedade, onde se adquire direito real por alienação e direito pessoal, por obrigação. Que a propósito, concebera por obrigação apenas as relações derivadas de um contrato, de um quase contrato, de um delito, de um quase delito ou da lei.

Demolombe torna-se principal expoente da doutrina clássica, sob a qual o Direito real é absoluto oponível erga omnes, enquanto o direito obrigacional é relativo a uma pessoa determinada ${ }^{17}$.

Sempre tentando encaixar a propriedade de forma a se tornar um direito absoluto, "Demolombe fez todos os esforços para definir a propriedade como o poder de uma pessoa sobre a coisa" ${ }^{\prime 18}$.

A melhor maneira de tornar absoluto o direito de propriedade, na concepção do séc. XIX, seria enquadrá-la sob a forma de direitos reais. Essas questões implicariam em uma análise sobre domínio, porem a tradição francesa do direito civil, ao que nos parece, sempre encontrou dificuldades para caracterizá-lo e distingui-lo em relação à propriedade.

Essa situação reafirmava o que propunha a doutrina clássica sob a qual o Direito real é absoluto oponível erga omnes, enquanto o direito obrigacional é relativo a uma pessoa determinada ${ }^{19}$.

Ao comentar que a definição de domínio dada pelo artigo 544 do Código de Napoleão rigorosamente era uma definição de propriedade, Proudhon explicava que a diferenciação entre domínio e propriedade sempre foi uma questão árdua de ser enfrentada. Considerava

\footnotetext{
${ }^{16}$ Vide KANT. Introduction, § III. Doctrine du droit, Métaphysique des moeurs. Tradução francesa de A. Renaut. Paris: GF, 1994 (1795), p. 29, apud XIFARAS, Mikhaïl. op. cit., 2004, p. 30 (tradução nossa). - O jurista francês Marcel Planiol continuou a inquietação proposta por Kant e o debate com a escola clássica do direito civil. Washington de Barros relata que Planiol não admitia a relação jurídica entre pessoa e coisa, entendendo que no direito de propriedade, a relação jurídica somente poderia se estabelecer entre pessoas. (PLANIOL. Traité élémentaire de droit civil. 12. Ed. v. 1, $\mathrm{n}^{\circ} 2.158$ apud MONTEIRO, Washington de Barros. op. cit., 2000, p. 9.)

${ }^{18}$ XIFARAS, Mikhaïl. op. cit., 2004, p. 43

${ }^{19}$ XIFARAS, Mikhaïl. op. cit., 2004, p. 32.
} 


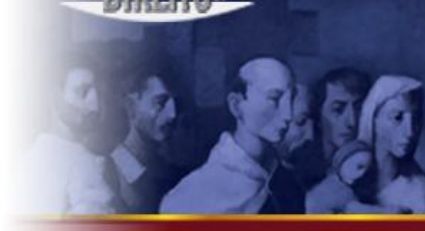

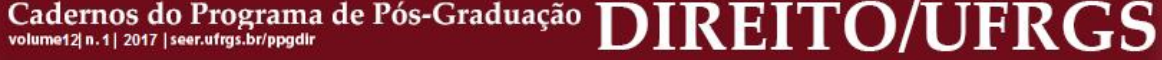

esse enfrentamento como uma distinção metafísica e que domínio e direito de propriedade são confusos, mesmo na linguagem da lei. ${ }^{20}$

Charles Toulliers, outro teórico do séc. XIX, entendia que o domínio era ligado à pessoa, ao passo que a propriedade estaria ligada diretamente à coisa. O que o levava a crer que domínio e propriedade eram termos correlatos; um sendo o direito ativo de dispor, enquanto o outro, uma qualidade passiva que segue à coisa, sempre à disposição do proprietário. Essa distinção que para Pufendorff era sem uso prático, servia para responder teoricamente a natureza do direito de propriedade. ${ }^{21}$

Defendendo que o direito de propriedade seria uma relação pessoal e não real, Ricardo Aronne nos conduz a refletir sobre a divergência ontológica do direito de propriedade sobre a concepção da civilistica clássica. Para Aronne, "a propriedade instrumentaliza o domínio"22 e sua oponibilidade erga omnes seria uma característica de direito pessoal e obrigacional, na medida em que, o direito de propriedade é oponível contra todos para o pleno exercício do domínio.

Domínio e propriedade seriam institutos complementares e autônomos, mas as feições atribuídas à propriedade estariam mais condizentes com uma assunção de direitos pessoais, em razão do direito de exclusão, pois o proprietário exclui todos os demais que disputam o direito de usar, gozar e dispor do bem.

Segundo José Serpa de Santa Maria, “a propriedade significa que a coisa está reservada somente ao proprietário, de forma que os demais sem direito, não podem subtraí-la ou retê-la, nem perturbá-la ou prejudicar de outro modo o exercício de seu domínio real $[\ldots]^{, 23}$. O conceito revela que o direito de propriedade possui um aspecto interno de feições

\footnotetext{
20 "Mais malgré cette distinction qui, dans le langage métaphysique paraît fort juste, souvent le domaine et le droit de propriété sont confondus et pris l'un pour l'autre, même dans le langage des lois: c'est ainsi que, rigoureusement parlant, c'est plutôt la définition du domaine que celle de la propriété qui nous est donnée dans l'article 544." (DEMOLOMBE, Charles. Traité de la distinction des personnes et des biens. Cours de Code Napoléon. Tomo IX. Paris: Durand, 1870, n. 443, p. 462, apud XIFARAS, Mikhaill. op. cit., p. 94)

21 "Et par le domaine, ils entendent le droit de disposer à notre gré de ce qui nous appartient, droit qu'ils regardent comme l'effet de la propriété; de sorte que selon eux, le domaine est attaché à la personne, au lieu que la propriété est attachée à la chose même. Ainsi domaine et propriété seraient deux termes corrélatifs; l'un serait le droit actif de disposer, l'autre une qualité passive qui suit toujours la chose, et la soumet à la disposition du propriétaire." "Cette distinction trop subtile, comme l'a fort bien observé Pufendorff, ne peut être d'aucun usage dans la propriété; mais en théorie, elle peut répandre du jour sur la nature du droit de propriété." (TOULLIER, Ch.-M. Droit civil français suivant l'ordre du Code, ouvrage dans lequel on a tâché de réunir la théorie et la pratique. v. III. Paris: Renouard, 1839, $\mathrm{n}^{\circ}$ 83, p. 55, apud XIFARAS, Mikhaïl. op. cit., p. 94).

${ }^{22}$ ARONNE, Ricardo. Propriedade e domínio: reexame sistemático das noções nucleares de direitos reais. Rio de Janeiro: Renovar, 1999, p. 136.

${ }^{23}$ SANTA MARIA, 1991, p. 53 apud ARONNE, Ricardo. op. cit., p. 155. (tradução nossa).
} 


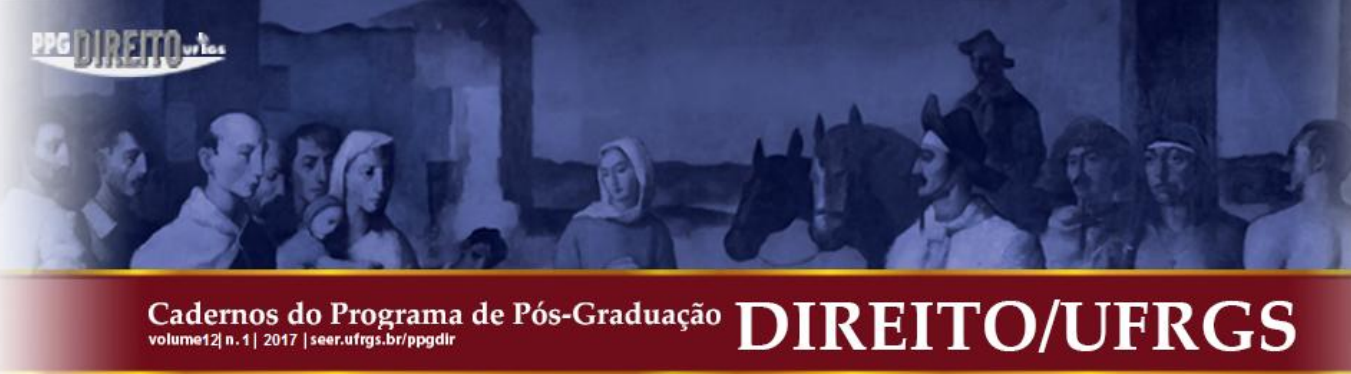

econômicas $^{24}$ e outro externo de feições jurídicas ${ }^{25}$. O aspecto interno revela os poderes que o proprietário detém sobre a coisa. Poderes tradicionalmente exercidos pelo jus utendi, jus fruendi et jus disponendi que identificam a fluência econômica sobre o bem. As feições externas exibem o poder de exigir a abstenção de terceiros em relação à propriedade.

As feições interna e externa da propriedade revelam uma dicotomia entre o tratamento que se aplica em relação à coisa e o tratamento que se espera em relação às pessoas, um de caráter real e outro de caráter pessoal. Esse tratamento conduziu a doutrina a uma bifurcação que ora identifica integralmente o domínio com a propriedade, numa condição de sinonímia, ora identifica o domínio com caráter, conteúdo e profundidade completamente diversos da identificação que se confere à propriedade. Situação que Proudhon, considerava uma distinção metafísica e que Pufendorff entendia ser eminentemente teórica, sem finalidade prática.

Comparando-se o artigo 527 do revogado Código Civil Brasileiro de 1916 com a redação do artigo 1.231 do Código Civil de 2002, verifica-se que subsiste a identidade entre domínio e propriedade. Alia-se a esse fato a elevação axiológica da propriedade a uma condicionante, presente no ordenamento constitucional, que promove uma funcionalização do direito de propriedade, denominado de princípio constitucional da função social.

A partir dessa funcionalização da propriedade, observou-se que o emprego da característica tida como absoluta, conferida aos direitos reais pela escola clássica do direito civil deixou de ter sentido pois, a propriedade passou a integrar o Estado Constitucional e os princípios inerentes ao bem estar social e a justiça social e distributiva.

Ao se conceber o direito de propriedade como direito pessoal, a propriedade revela-se no exercício de uma relação entre pessoas, onde o sujeito passivo é indeterminado. A coletividade tem o dever jurídico de se abster de atos que atentem contra a coisa alheia. A relação não se dá entre o proprietário e o objeto, mas entre o sujeito ativo e a coletividade, no sentido de se proteger das perturbações que terceiros possam exercer sobre o objeto.

Característica desse fato decorre da reivindicação sob a forma de exercício de pretensão material excludente em relação às pessoas e não em relação direta com o objeto. Aronne nos fala que haveria uma prestação, onde o "proprietário é credor de uma obrigação

\footnotetext{
${ }^{24}$ Vide TEPEDINO, 1997, p. 311 apud ARONNE, Ricardo. op. cit., p. 59-60.

${ }^{25}$ ARONNE, Ricardo. op. cit., p. 59-60.
} 


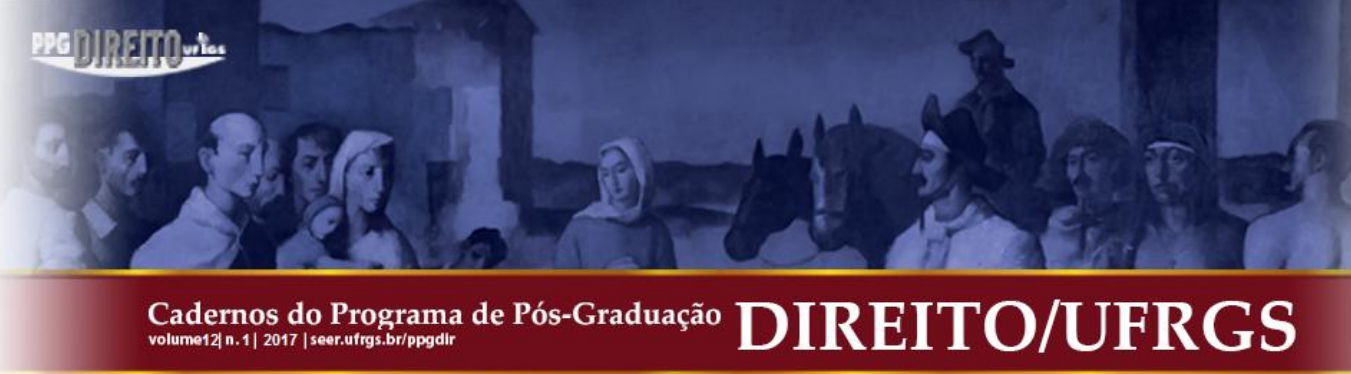

passiva universal, e uma obligacio por parte dos demais indivíduos e Estado, de respeito e não de ingerência no bem"26.

Arnoldo Wald chega a afirmar que "não existe relação jurídica, no direito de propriedade antes da lesão contra ele perpetrada, mas apenas sujeição da coisa à vontade do proprietário"27. Em outras palavras, a propriedade exclui.

O domínio, por sua vez, tem por objeto a coisa e as faculdades dela decorrente, ambas com natureza real, enquanto a propriedade teria natureza pessoal.

Ricardo Aronne faz uma análise histórica do domínio e da propriedade a partir de estudos do romanista Eugène Petit ${ }^{28}$, que baseando-se numa comparação entre textos romanos originários e glosas medievais, concluiu que o axioma ius in re aliena atribuído à propriedade, na verdade tratava-se de uma relação obrigacional ${ }^{29}$.

Aronne apresentou um exemplo sobre o qual o proprietário de um terreno ribeirinho deveria tolerar o uso público de suas margens. Concluiu que esta seria uma obrigação de suportar e que, por não se tratar de uma servidão, não se inseriria no âmbito real. $O$ proprietário poderia usar, fruir e dispor da integralidade do bem, revelando possuir completo domínio sobre o mesmo (domínium est in plena re potestas), apesar de não poder opor seu direito in personam, para obstar o uso público da referida margem ${ }^{30}$. Assim haveria uma funcionalização da propriedade e não do domínio, cuja oposição deste estaria congelada pela propriedade.

O exemplo ilustra os limites intersubjetivos da obrigação passiva universal de que outros, inclusive o ente público, se abstivessem de perturbar o exercício em substância do direito, de usar, fruir e dispor da coisa.

Há de se concluir que o problema de limitação ao exercício da propriedade não seria objeto de direito real, ao passo que os poderes de domínio (usar, fruir e dispor) estariam todos à disposição do senhorio, que poderá exercê-los livremente em relação à coisa, inclusive transferindo-os a terceiros, porém guardando a limitação imposta pelo ente público ao exercício da propriedade.

\footnotetext{
${ }^{26}$ ARONNE, Ricardo. op. cit., p. 94.

${ }^{27}$ WALD, Arnoldo. Direito das coisas. 10. ed. São Paulo: RT, 1995, p. 98.

${ }^{28}$ PETIT, 1892, p. 240 apud ARONNE, Ricardo. op. cit., p. 103.

${ }^{29}$ Vide ARONNE, Ricardo. op. cit., p. 103.

${ }^{30}$ ARONNE, Ricardo. op. cit., p. 102-103.
} 


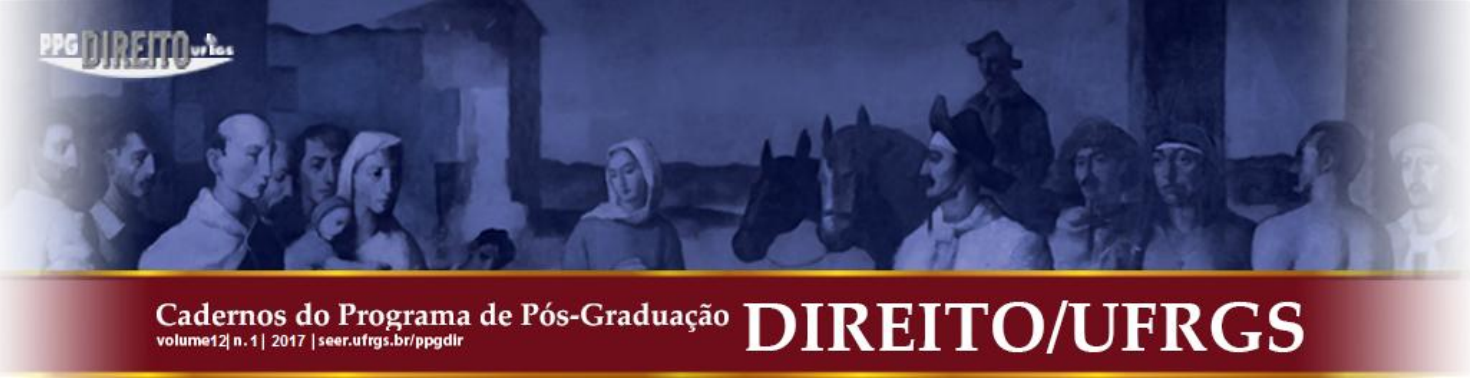

Para Aronne, o domínio seria: "complexo de todos os direitos possíveis no bem, próprio ou de outrem, materializados nas respectivas relações entre o titular e o bem da vida objeto deste" 31 .

O domínio em sua natureza seria um direito real por excelência, embora não integre a codificação com esse sentido. Parte das relações existentes entre o indivíduo e o objeto de onde se emerge o exercício dos direitos dominiais.

Sob esse enfoque, torna-se bem nítido que a natureza do domínio é de direito real, enquanto a da propriedade seria de direito pessoal, embora a lei assim não entenda, tanto que a codificação civil excluiu o domínio da legislação material e deu status de direito real à propriedade.

\section{AS INDICAÇÕES GEOGRÁFICAS E O DIREITO DE PROPRIEDADE}

As teorias do sec. XIX, que embasavam o direito de propriedade como direito real, foram construídas em cima do postulado de que a propriedade era constituída por bens tangíveis. Pontes de Miranda ao analisar os direito reais sobre bens incorpóreos relatou que "o substrato filosófico dos juristas gregos e romanos e dos próprios juristas medievais e pósmedievais não lhes permitia que vissem haver res incorporales que podia ser objeto de direitos reais" ${ }^{32}$.

Os direitos sobre coisas incorpóreas e bens imateriais surgem a partir do séc. XX, e ainda é uma tarefa árdua para a doutrina enfrentá-los com o discurso do direito de propriedade. Poucos civilistas o fizeram com maestria e muitos se calaram diante de uma incógnita: como poderiam direitos de uma mesma natureza ser tidos como exceção?

A resposta a esta pergunta, até os dias atuais, possui uma dubiedade impar. Ao se considerar o direito de propriedade como direito real como seria possível explicar que as características dos direitos reais não se aplicam totalmente aos direitos sobre bens intangíveis.

Dentre as características principais dos direitos reais de caráter originário, destaca-se a característica de ser suscetível de posse e de ter por um dos meios de aquisição a usucapião. Algumas dessas características não se encaixam na propriedade imaterial ou intelectual. O que

\footnotetext{
${ }^{31}$ Vide ARONNE, Ricardo. op. cit., p. 115.

${ }^{32}$ MIRANDA, Pontes de. Tratado de direito privado. 4. ed. v. 60. Tomo XVI. Parte Especial. São Paulo: RT, 1983, p. 377. 


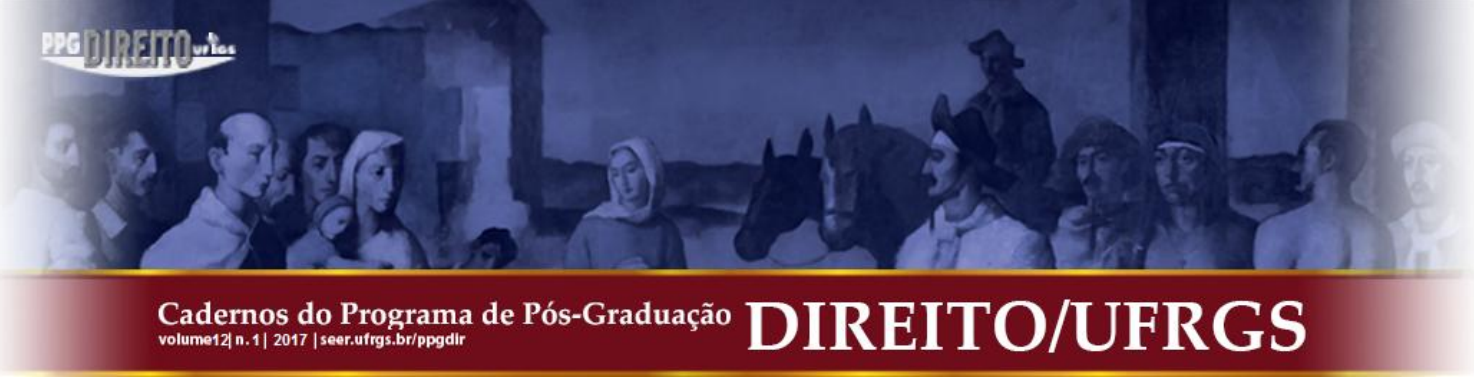

torna intrigante a sua limitação como direito real, pois se são direitos de propriedade deveriam assumir as mesmas características da origem.

Ao discorrer sobre a propriedade intelectual, Pontes de Miranda chegou a afirmar que "a claridade a que a ciência chegou, no tocante à propriedade intelectual, serviu para que se iluminassem os caminhos, por vezes obscuros, que os juristas percorriam, no trato da

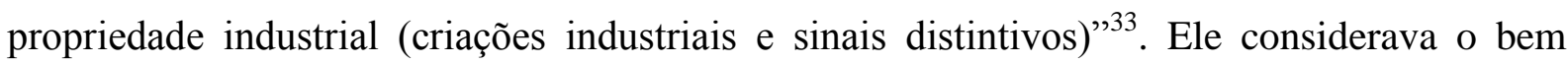
intelectual como objeto de direito real, independentemente de qualquer formalidade. Entendia que as criações industriais somente tornavam-se objeto de direito real após serem patenteadas, excetuando as "indicações de proveniência" 34 e os sinais distintivos, que se tornariam objeto de direitos reais após o registro. ${ }^{35}$

A excepcionalidade desses direitos pode ser observada, inicialmente, por não serem suscetíveis de posse, ao passo que a propriedade móvel ou imóvel sobre bens tangíveis é suscetível de apossamento independentemente de se haver constituído direito dominial ou de propriedade.

Tais exceções têm levado a posicionamentos que colocam a propriedade intelectual na categoria de novos direitos, pois a apropriação de bens imateriais ocorre de forma diversa da apropriação de bens materiais. Situação que segundo Xifaras e Renouard, possibilitaria a discussão de uma forma alternativa de propriedade. ${ }^{36}$

\footnotetext{
${ }^{33}$ MIRANDA, Pontes de. op. cit., Tomo XVI, p. 377.

${ }^{34}$ Indicações de proveniência, indicações de procedência e denominações de origem, são conceitos distintos, mas que devido a uma imperfeição da linguagem legislativa veio a causar demasiada confusão na doutrina. $\mathrm{O}$ conceito de indicação de proveniência, por muitos não é considerado indicação geográfica, mas mera figura para indicar a origem dos produtos. Pontes de Miranda a utiliza no sentido de indicação de procedência.

${ }^{35}$ MIRANDA, Pontes de. op. cit., Tomo XVI, p. 378.

${ }^{36}$ Xifaras dialoga com as ideias de Renouard nos comentários sobre o artigo 544 do Código Civil dos Franceses, em uma análise sobre o direito absoluto atribuído à propriedade e as categorias e possibilidades do domínio: "L'existence même de droits privatifs des auteurs sur leur œuvre littéraire ou scientifique nous apparaît donc, au premier abord, sous la forme d'un paradoxe: comment penser l'appropriation privative d'un domaine inappropriable par nature? Comment penser une appropriation qui n'en soit pas une, qui ne soit pas celle que porte l'article 544, alors que la glose fidèle de la lette de cet article fournit, selon Renouard, le seul sens juridique qu'on puisse assigner au terme 'appropriation'? En refusant d'inscrire l'empire que les particuliers exercent sur leurs idées dans la même sphère que les biens matériels appropriables, Renouard se voit contraint de bâtir une conception alternative de la propriété et de lui trouver un nom qui évite qu'on la confonde avec le seul domaine qui mérite, selon lui, d'être qualifié de propriété, à savoir celui de l'homme sur les choses matérielles, tel qu'il est déterminé par l'article 544. Cette rigueur sémantique pourrait faire douter qu'il soit possible de voir dans ce domaine réservé une conceptualisation de l'institution de propriété au sens générique du terme, si Renouard ne précisait explicitement, et à plusieurs reprises, que dans son esprit le mot propriété ne désigne que le droit établi par l'article 544, et que le droit d'auteur, pour n'être pas de même nature, n'en est pas moins un droit privatif comportant une dimension patrimoniale, qui réalise donc bien, n'en déplaise à la terminologie adoptée, une appropriation privative des œuvre. C'est donc contre la lettre du Traité, mais en plein accord avec son esprit,
} 


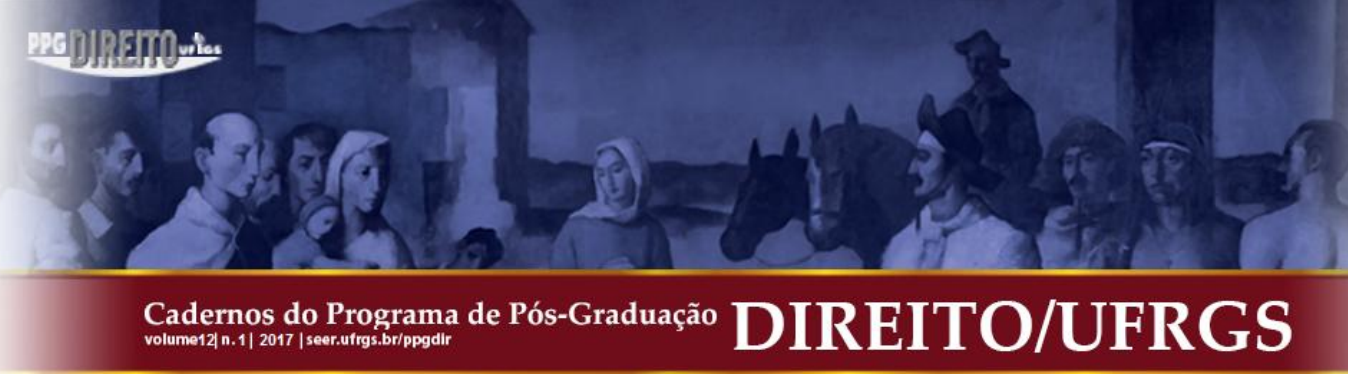

O direito de propriedade em relação às indicações geográficas obedece a outras exceções que não são características dos direitos reais.

Dentre as indicações geográficas, uma em especial chama a atenção: a denominação de origem. Essa, por excelência, seria a classificação mais elevada, pois sob o seu crivo concorrem os fatores naturais e humanos, tais como a terra, o clima, todos os elementos naturais a eles agregados e também o homem com o seu conhecimento e suas técnicas. Todos esses fatores são contabilizados pelos meios naturais, leais e constantes que concorrem para a singularidade do produto e da cadeia produtiva que o compõe.

As indicações geográficas têm sido classificadas como sinais distintivos, entretanto, não se resumem a isto. Especialmente a denominação de origem, que agrega valores culturais em seu sistema. Esses valores não são adquiridos de uma hora para outra, mas se estabelecem em uma linha temporal que confere característica a uma região, a uma determinada localidade e consequentemente a um produto que se destaca. Tradicionalmente a maioria desses produtos estão associados ao meio agrário.

A agregação desses valores se dá por meio do reconhecimento que ocorre pelo registro. Ao analisar a indicação de proveniência, Pontes de Miranda a concebia como bem incorpóreo. Um direito de propriedade que devido ao caráter territorial do que se indica e da característica de "titularidade coletiva (a indicação não é res communis omnium, mas de muitos) da indicação de proveniência, não pode ser alienada, nem é suscetível de penhor ou de qualquer medida constritiva" ${ }^{37}$. Salientou, Pontes de Miranda, que o direito de aquisição à indicação de proveniência seria sempre originário, irrenunciável e não se perderia pelo não uso. A renúncia seria sem alcance, uma vez que outros poderiam adquirir o direito satisfazendo os pressupostos. ${ }^{38}$

O registro é uma das formas de se fazer com que a propriedade intelectual ingresse no universo dos direitos reais e venha a se tornar objeto de direito. Entretanto as indicações geográficas não se sujeitam à propriedade exclusiva de ninguém. Embora seja objeto do direito de propriedade ela não pode ser vendida ou destacada da terra, da região ou do produto.

qu'on décèlera dans ce domaine réservé une nouvelle conceptualisation de la propriété”. (XIFARAS, Mikhaill. op. cit., p. 354-355).

${ }^{37}$ MIRANDA, Pontes de. op. cit., Tomo XVI, p. 196.

${ }^{38}$ MIRANDA, Pontes de. op. cit., Tomo XVI, p. 196. 


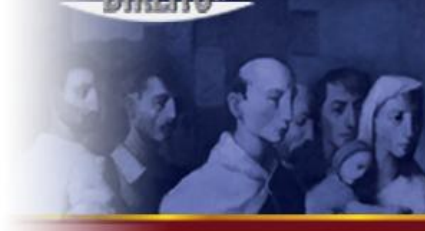

\section{Cadernos do Programa de Pós-Graduação
volume12|n.1| 2017| seer.utrgs.br/ppgdir}

Uma vez que haja o reconhecimento da indicação geográfica todos os que congregam as condições definidas para o reconhecimento e registro das indicações geográficas passam a ter domínio sobre a mesma. ${ }^{39}$

Concebê-la apenas como uma marca ou um sinal distintivo seria reduzir sua importância. Para uma denominação de origem, por exemplo, não seria possível aliená-la, como uma marca, para que outros a explorassem. Caso isso ocorresse haveria uma descaracterização do instituto em análise. Os fatores leais e constantes que assumem a sua característica não estariam mais presentes até que o sinal distintivo se tornasse de uso comum e não mais servisse para identificar as condições naturais e humanas, determinantes para singularizar o produto. Por outro lado, qualquer um que estivesse na região demarcada e cumprisse com os requisitos definidos, geralmente em um regulamento, poderia produzir e se utilizar da denominação de origem ou da indicação geográfica.

Tradicionalmente o registro das indicações geográficas é titularizado por associações ou cooperativas de produtores. Pessoas que detém um interesse em comum, ligados por similaridades à determinada região, buscam o reconhecimento e o registro da indicação geográfica. Mas, uma vez reconhecida, não podem vender, transferir, alugar, nem coletiva e nem individualmente. $\mathrm{O}$ registro é mera formalidade para se dizer que elementos naturais e culturais são relevantes para a produção de determinado produto.

Essas características nos levam a concluir que especialmente a denominação de origem, em decorrência dos fatores naturais e humanos, e dos meios constantes e leais de produção, integram o patrimônio natural e cultural de uma região.

Ressalta-se a possibilidade da inclusão das indicações geográficas na classificação de Renouard que, ao distinguir o direito dos objetos de direito, e dentre estes o domínio material

\footnotetext{
${ }^{39}$ Pontes de Miranda, em análise sobre a indicação de proveniência (leia-se indicação de procedência), a considerava como uma das mais interessantes figuras jurídicas do direito privado, pois segundo ele: "Não há laços entre os titulares; nem o direito de um limita o direito de outro. Nem há sequer comunhão pro diviso. $\mathrm{O}$ fato de ser objeto de direito real, bem incorpóreo permitiu que se tivesse como suscetível de pluralidade de titulares, sem qualquer comunhão, a indicação de proveniência. [...] Os sindicatos de produtores e outras entidades coletivas podem usar a indicação de proveniência e tal indicação de jeito nenhum se confunde com a marca coletiva de indústria e de comércio, cuja estrutura jurídica já foi descrita. [...] A pluralidade de direitos de que aqui se cogita é semelhante à dos pastos comuns ou compáscuo [...]. Frise-se, porém, que o direito à indicação de proveniência, posto que tenham muitas pessoas, não é compropriedade. Cada pessoa, que satisfaça os pressupostos, o adquire. Não há comunhão pro indiviso, em pro diviso: a titularidade é, talvez, de muitos, mas cada um é titular do seu direito, que somente é exclusivo em relação aos que não satisfaçam os pressupostos. Não há que pensar-se em invocação, por analogia, das regras jurídicas sobre condomínio. Se há ofensa ao direito à indicação de proveniência, qualquer dos titulares, independentemente dos outros, pode exercer a pretensão à tutela jurídica. Não há compropriedade, nem prioridade." (MIRANDA, Pontes de. Tratado de direito privado. 4. ed. v. 60. Tomo XVII. Parte Especial. São Paulo: RT, 1983, p. 200-201).
}

Cadernos do Programa de Pós-Graduação em Direito PPGDir./UFRGS | Edição Digital | Porto Alegre | Volume XII | Número 1 | 2017 | P. 300 - 320 


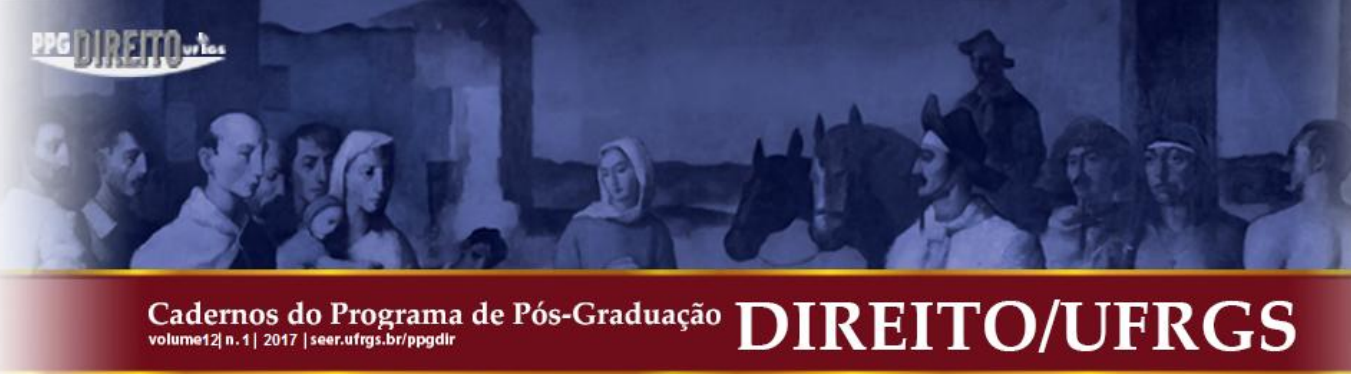

do domínio imaterial, distingue quatro categorias passíveis de domínio: o domínio material apropriável e o inapropriável, e o domínio imaterial apropriável e o inapropriável; onde seriam os domínios materiais e imateriais inapropriáveis concebidos como domínios universais. Enquanto o domínio material apropriável constituiria o domínio da propriedade, o domínio imaterial apropriável seria concebido como o domínio imaterial da propriedade. Através das ideias sobre o objeto de direito, Renouard consegue pensar o domínio inapropriável ou universal, que seriam excluídos pela concepção patrimonial de propriedade. $^{40}$

Se na vertente clássica do direito de propriedade as indicações geográficas estariam sobre a égide do domínio imaterial apropriável (conforme é possível verificar nas valiosas lições do mestre Pontes de Miranda), ao admiti-las como integrantes do patrimônio cultural e natural de uma região, estar-se-ia na verdade afirmando a sua natureza de domínio universal inapropriável. Consequentemente, de natureza jurídica contrária à doutrina clássica. Logicamente mais condizente com a situação singular desse instituto no direito de propriedade e que o excluiria do âmbito das inúmeras e inexplicáveis exceções que embasam a discussão entre domínio e propriedade no campo dos direitos reais.

\section{NATUREZA JURÍDICA DAS INDICAÇÕES GEOGRÁFICAS}

Ribeiro de Almeida ${ }^{41}$ apresenta uma análise sobre a natureza jurídica da denominação de origem, a qual sintetizamos, e que entendemos poder ser estendida para as outras figuras, tanto a indicação geográfica quanto a indicação de procedência.

Dentro do sistema das indicações geográficas, a denominação de origem é uma figura de maior relevância. Em seus atributos exige-se a conjugação de fatores naturais e humanos. Já, a indicação de proveniência e a indicação geográfica protegida (no caso de Portugal) não exige a conjugação desses atributos específicos.

Sobre as teorias que fundamentam a natureza jurídica desse instituto, M. Plaisant e F. Jacq admitem o caráter imaterial e coletivo da denominação de origem, concebendo-a na

\footnotetext{
${ }^{40}$ Vide RENOUARD apud XIFARAS, Mikhaïl. op. cit., p. 353-354.

41 ALMEIDA, Alberto Francisco Ribeiro de. Denominação de origem e marca. Coimbra: Universidade de Coimbra, 1999, p. 102-115.
} 


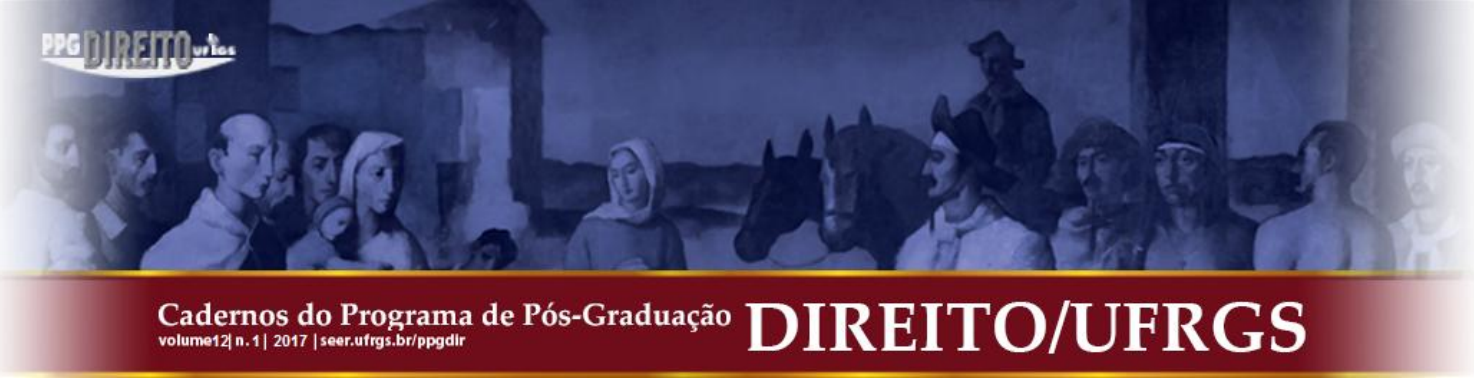

categoria de direitos pessoais ou de crédito, sob a forma de "direito de participação numa sociedade pública",42.

Por outro lado, M. David concebe a natureza jurídica da denominação de origem sob a forma de "direito mobiliário" 43 com relevância ao produto:

O laço que une a (DO) à terra é apenas indireto. Não é o solo que nos interessa em si mesmo, mas o produto. O solo só nos interessa como fator de qualidade, e a qualidade aprecia-se através do produto. O direito ao nome está ligado diretamente ao produto. E é por isso que aí vemos um direito mobiliário". ${ }^{4}$

Como melhoramento da teoria do direito mobiliário, M. Vivez concebeu a "teoria de direito acessório de um direito da propriedade sobre uma coisa móvel". A ligação mediata do produto à denominação de origem seria de forma indireta, efetuando-se através da qualidade do produto. Uma forma de direito acessório ao direito de propriedade. ${ }^{45}$

Ribeiro de Almeida também fala sobre a teoria do "direito imobiliário" $"$. Essa teoria insere a denominação de origem como uma servidão que onera um prédio. Segundo Almeida:

\begin{abstract}
Aqui tratar-se-ia de um direito inerente à todas as parcelas agrícolas ou terrenos que fazem parte da área geográfica da DO e conferindo-lhe, ao contrário da servidão clássica, uma valorização econômica. A DO pela sua particular ligação ao solo seria entendida como um imóvel incorpóreo, um direito imobiliário. Uma tal teoria afasta qualquer ligação da DO ao estabelecimento comercial. Na verdade, aqui, o titular do direito sobre o sinal distintivo seria o proprietário do solo, quer explore ou não a DO. O arrendatário do imóvel, por sua vez, seria apenas concessionário de tal direito. $^{47}$
\end{abstract}

Dentre alguns fatores que Ribeiro de Almeida aponta no sentido de inviabilizar a aplicação da teoria do direito imobiliário, destaca-se no âmbito deste trabalho, que a servidão predial adere ao imóvel, e nesse sentido a DO transmitir-se-ia com o direito imobiliário. Conforme dito na seção anterior sobre o direito de propriedade, nem a DO, nem a IG ou a IP, têm caráter de alienabilidade. Almeida considera que se o adquirente do imóvel efetua nova cultura que não corresponda à típica cultura da região, a qual foi registrada como DO, não

\footnotetext{
${ }^{42}$ PLAISANT, M. ; JACQ. F. Traité des noms \& appellations d'origine. Paris, 1921, apud ALMEIDA, Alberto Francisco Ribeiro de. op.cit., p. 102-103.

${ }^{43}$ DAVID, M.. La nouvelle législation des appellations controlées. Paris: Faculté d'Aix, 1938, apud ALMEIDA, Alberto Francisco Ribeiro de. op.cit., p. 103.

${ }^{44}$ DAVID, M.. La nouvelle législation des appellations controlées. Paris: Faculté d'Aix, 1938, p. 218 et seq. apud ALMEIDA, Alberto Francisco Ribeiro de. op.cit., p. 103.

45 VIVEZ. Traité des appellations d'origine. Paris: R. Pichon \& Durand-Auzias, 1943, apud ALMEIDA, Alberto Francisco Ribeiro de. op.cit., p. 104.

${ }^{46}$ ALMEIDA, Alberto Francisco Ribeiro de. op.cit., p. 105.

${ }^{47}$ ALMEIDA, Alberto Francisco Ribeiro de. op.cit., p. 105. 


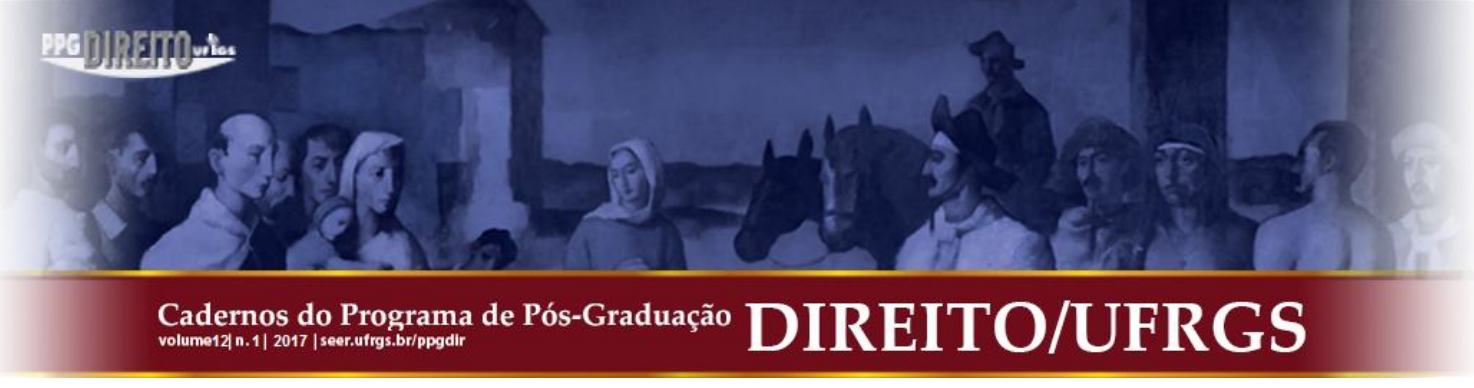

seria possível que o adquirente continuasse a ser titular da DO, pois a parcela agrícola constitui suporte para a elaboração da denominação de origem. ${ }^{48}$

Sob a égide do "direito real e institucional", M. Malapas inspirado na teoria institucionalista de Maurice Hauriou defendia que a DO é direito real cuja origem provem de um "conjunto de regras impostas pelo legislador, pela corporação ou pela jurisprudência para que a denominação de origem pudesse preencher a sua função social"49. Segundo Almeida, essa função social seria "a proteção ao consumidor"

Destaca-se ainda, a "teoria do monopólio concedido pela autoridade estatal", defendida por Auby e Pleisant ${ }^{51}$ que criticavam a ideia de caráter exclusivo da DO, sob a forma de direito de propriedade, que se opunha ao caráter coletivo:

Em definitivo, o direito à denominação de origem aparece como um dos casos de monopólio legal, cujo fundamento é o esforço criador dos beneficiários, que o legislador protege estatutariamente no interesse destes, mas também no interesse geral. ${ }^{52}$

$[\ldots]$

Como os outros direitos da propriedade intelectual, o direito à denominação de origem é um monopólio concedido pela autoridade pública para certos fins definidos e segundo as condições que impõem estes fins. ${ }^{53}$

Jean-Michel Aubouin defendia, ainda, a teoria da "denominação de origem como marca coletiva que constitui um direito absoluto de natureza fundiária"54. Para essa teoria a natureza jurídica da denominação de origem seria de um tipo particular de marca coletiva, que na visão de Aubouin não pertenceria apenas ao produtor, mas também ao consumidor. A denominação de origem, como marca coletiva, seria um direito absoluto de natureza fundiária. Aubouin não aceitava ser um direito de propriedade (ou outro direito real), ou também um direito pessoal. Ele se afastou da tradicional classificação de direitos reais e direitos pessoais e

\footnotetext{
${ }^{48}$ ALMEIDA, Alberto Francisco Ribeiro de. op.cit., p. 106.

${ }^{49}$ MALAPAS, M. Jean apud ALMEIDA, Alberto Francisco Ribeiro de. op.cit., p. 106.

${ }^{50}$ ALMEIDA, Alberto Francisco Ribeiro de. op.cit., p. 107.

51 AUBY, Jean-Marie; PLAISANT, Robert. Le droit des appellations d'originne, l'Appellation Cognac. Paris, 1974, p. 67 et seq. e 391 et seq. apud ALMEIDA, Alberto Francisco Ribeiro de. op.cit., p. 107.

${ }^{52}$ AUBY, Jean-Marie; PLAISANT, Robert. Le droit des appellations d'originne, l'Appellation Cognac. Paris, 1974, p. 92 apud ALMEIDA, Alberto Francisco Ribeiro de. op.cit., p. 108.

53 AUBY, Jean-Marie; PLAISANT, Robert. Le droit des appellations d'originne, l'Appellation Cognac. Paris, 1974, p. 392 apud ALMEIDA, Alberto Francisco Ribeiro de. op.cit., p. 108.

${ }^{54}$ AUBOUIN, Jean-Michel. Le droit au nom de Cognac. Paris, 1951, p. 128 et seq. apud ALMEIDA, Alberto Francisco Ribeiro de. op.cit., p. 110.
} 


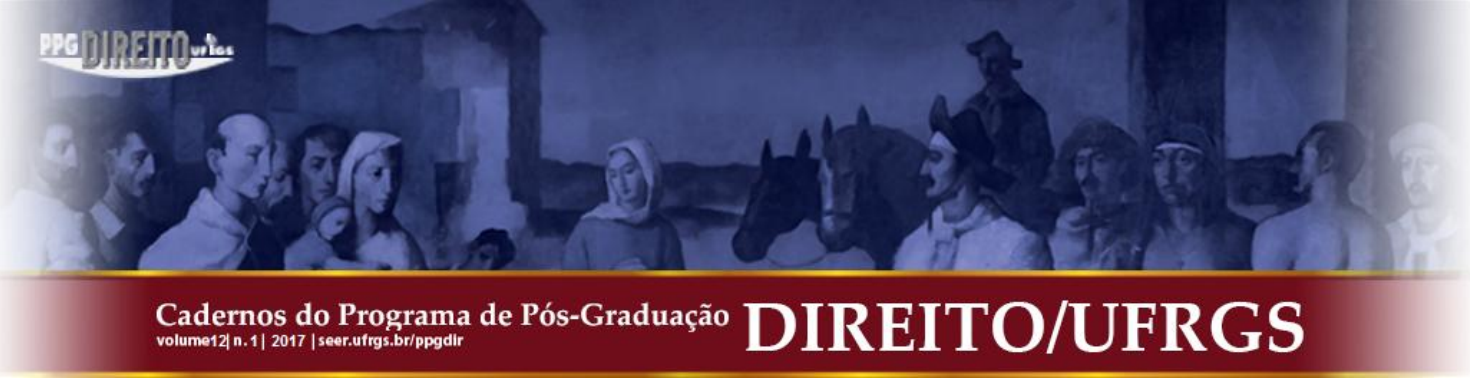

concebeu a denominação de origem e os demais direitos sobre a propriedade industrial, colocando-os na categoria de novos direitos, de caráter absoluto e oponível erga omnes. ${ }^{55}$

Os fatores naturais, físicos e climáticos decorrentes da delimitação geográfica são os elementos que fazem da DO um direito imobiliário, ligado a terra. Bem de natureza fundiária. É, neste aspecto, uma marca coletiva que demonstra a relação entre a terra e a população, cujo trabalho de gerações de camponeses, conceberam, juntamente com o clima e o solo, um ideal de perfeição que confere as características singulares a um produto, em particular, típico da região. $^{56}$

\section{CONCLUSÃO}

A incursão ao direito de propriedade propiciada neste trabalho não teve por objetivo elucidar questões há muito debatidas pela doutrina, dentre elas: se seria o direito de propriedade um direito real ou pessoal.

Apena, tentou-se demonstrar que em relação ao direito de propriedade, e mais especificamente sobre a propriedade intelectual, há lacunas que o coloca fora do modelo caracteristicamente adotado para os direitos reais de cunho material, do patrimônio e dos bens tangíveis.

A clássica definição de que os direitos reais, em especial os direitos sobre a propriedade seriam direitos absolutos foi superada, sem ater-se a uma análise que não invocou o debate sobre a função social da propriedade; já consagrada como excludente do absolutismo utópico do direito de propriedade.

Demonstrou-se que sob o aspecto do direito de propriedade não há exclusividade sob o instituto das indicações geográficas, como objeto do direito industrial ou da propriedade intelectual.

As indicações geográficas, como instituto correlato aos direitos sobre a propriedade industrial, imaterial, intelectual, ou do conhecimento, é um instituto jurídico bastante peculiar no rol dos direitos de propriedade.

Após uma análise circunstanciada, é possível afirmar com plena convicção, que as indicações geográficas é um instituto voltado aos direitos do conhecimento. Razão da

\footnotetext{
${ }^{55}$ Vide ALMEIDA, Alberto Francisco Ribeiro de. op.cit., p. 112.

${ }^{56}$ ALMEIDA, Alberto Francisco Ribeiro de. op.cit., p. 113-115. 


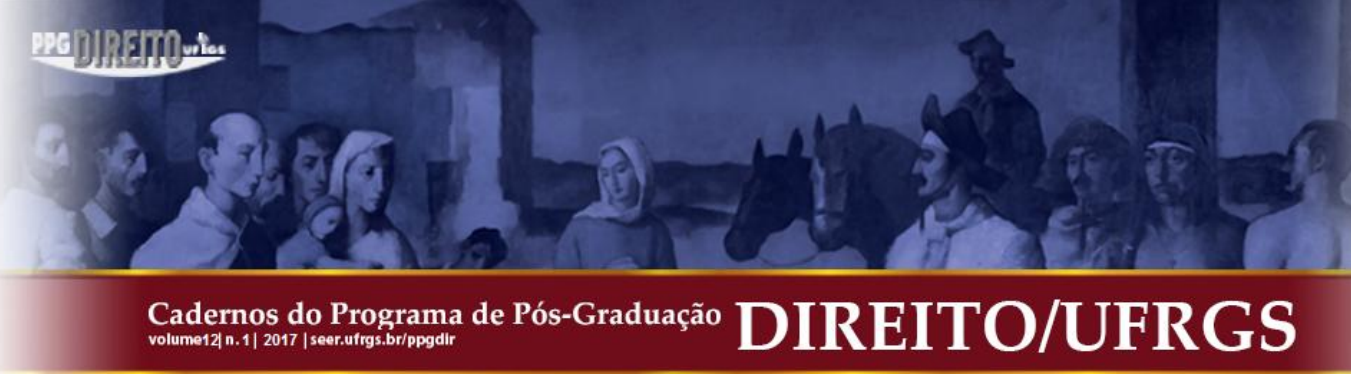

simbiose humana (técnica e cultural) sobre o meio natural. A natureza jurídica deste instituto está relacionada com o domínio universal inapropriável que integra o patrimônio cultural e natural de uma região.

Sob a forma de um direito acessório, é possível verificar que as indicações geográficas aderem à propriedade e permanecem enquanto existirem os fatores naturais, leais e constantes que a constituíram. A descaracterização de qualquer um destes fatores ensejaria o desaparecimento do reconhecimento.

É também um direito coletivo, podendo ser exercido por um grupo social, que em decorrência dos fatores culturais, leais e constantes, ou seja, do modo peculiar de tratamento de um determinado produto ou serviço, lhe confere uma singularidade que o destaca dentre os demais.

A importância das indicações geográficas sob as formas jurídica e comercial está justamente no fator de agregação cultural ao meio natural, o que possibilitaria, pelo menos em tese, a exploração sustentável e consciente dos sistemas produtivos, sobretudo os meios rurais, agrários e extrativistas, de forma a possibilitar melhoria dos padrões de vida do homem do campo e qualidade dos produtos relacionados à agroindústria.

\section{REFERÊNCIAS}

ALMEIDA, Alberto Francisco Ribeiro de. Denominação de origem e marca. Série Stvdia Ivridica n. 39. Coimbra: Universidade de Coimbra, 1999.

ALVES, José Carlos Moreira. Direito romano. 11. ed. v.1. Rio de Janeiro: Forense, 1998.

ARONNE, Ricardo. Propriedade e domínio: reexame sistemático das noções nucleares de direitos reais. Rio de Janeiro: Renovar, 1999.

BRASIL. Lei 9.279, de 14 de maio de 1996. Regula direitos e obrigações relativos à propriedade industrial. Diário Oficial da União, de 15 maio 1996. Disponível em: <http://www.planalto.gov.br/ccivil/leis/L9279.htm>. Acesso em: 20 jul. 2016.

FRANCE. Code civil des français: édition originale et seule officielle. A Paris, de l'Imprimerie de la République An XII 1804. Disponível em: <http://www.assembleenationale.fr/evenements/code-civil-1804-1.asp>. Acesso em: 20 jul. 2016.

KASER, Max. Direito privado romano. Tradução de Samuel Rodrigues e Ferdinand Hämmerle. Lisboa: Fundação Calouste Gulbenkian, 1999. 
MARÉS, Carlos Frederico. A função social da terra. Porto Alegre: Sérgio Antônio Fabris Editor, 2003.

MIRANDA, Pontes de. Tratado de direito privado. 4. ed. v. 60. Tomo XVI. Parte Especial. São Paulo: RT, 1983.

1983.

. Tratado de direito privado. 4. ed. v. 60. Tomo XVII. Parte Especial. São Paulo: RT,

MONTEIRO, Washington de Barros. Curso de direito civil. 36. ed. v. 3. São Paulo: Saraiva, 2000.

WALD, Arnoldo. Direito das coisas. 10. ed. São Paulo: RT, 1995.

WIEACKER, Franz. História do direito privado moderno. Tradução de A.M. Botelho Hespanha. 3. ed. Lisboa: Fundação Calouste Gulbenkian, 2004.

XIFARAS, Mikhaïl. La propriété: étude de philosophie de droit. Collection Fondements de la Politique. Paris: Press Universitaires de France, 2004.

Submissão: 20/07/2016

Aceito para Publicação: 11/08/2017 


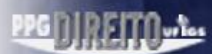

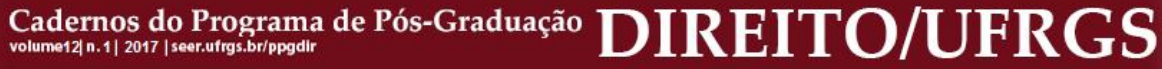

